\title{
Evaluasi Deskriptif Umur Panen Melon (Cucumis melo, L) Di Pekanbaru
}

\author{
Oleh: Surtinah \\ Program Studi Agroteknologi Fakultas Pertanian Universitas Lancang Kuning \\ e-mail:surtinah@unilak.ac.id
}

\begin{abstract}
Abstrak
Tujuan penelitian adalah untuk mengkaji faktor-faktor yang menyebabkan umur panen melon di Pekanbaru lebih cepat dibandingkan di daerah penghasil melon. Metode penelitian yang digunakan adalah deskriptif kualitatif terhadap hasil penelitian yang sudah dilakukan. Hasil pembahasan diperoleh bahwa Faktor-faktor yang mempengaruhi umur panen melon di Kota Pekanbaru adalah kondisi Stress air, Kandungan unsur esensial yang tidak terpenuhi, media tanam yang tidak cukup bahan organik, pentingnya zat pengatur tumbuh yang dapat memperbesar buah dan mempertahankan umur tanaman, dan perlu modifikasi lingkungan .

Kata Kunci: Umur panen, Melon, Stress air, Deskriptik Analitik.
\end{abstract}

\begin{abstract}
The objective of the study was to examine the factors that caused melon harvesting age in Pekanbaru faster than in the melon-producing regions. The research method used is descriptive qualitative. The results of the discussion found that the factors that influence the harvesting age of melon in Pekanbaru City are the water stress condition, the unfulfilled essential ingredients, the insufficient planting medium of organic matter, the importance of growth regulators that can enlarge the fruit and maintain the age of the plant, environmental modification.
\end{abstract}

Keywords: Harvest age, Melon, Water stress, Analytic Descriptive.

\section{PENDAHULUAN}

Melon (Cucumis melo L) salah satu tanaman buah yang sedang giat dikembangkan di Kota Pekanbaru. Pertambahan penduduk yang begitu pesat berdampak kepada pemenuhan kebutuhan akan pangan yang harus dipenuhi juga meningkat. Selain peningkatan jumlah penduduk, peningkatan pola pikir masyarakat tentang makanan yang bergizi dan sehat juga meningkat. Perkembangan Kota Pekanbaru disegala bidang, terutama di bidang pertanian tanaman hortikultura belum sebanding. Untuk memenuhi kebutuhan pasokan produk hortikultura biasanya didatangkan dari Sumbar dan Sumut.

Kandungan gizi yang terkandung dalam daging buah melon adalah 0,6 gram protein, $17 \mathrm{mg}$ calsium, 0,045 $\mathrm{mg}$ thiamin, 2,4 IU vitamin A, $30 \mathrm{mg}$ vitamin C, 0,045 $\mathrm{mg}$ vitamin $\mathrm{B}, 0,065 \mathrm{mg}$ vitamin $\mathrm{B} 2,6 \mathrm{mg}$ karbohidrat, $1 \mathrm{mg}$ niasin, 0,065 riboflavin, 0,4 $\mathrm{mg}$ zat besi, 0,5 gram nikotianida, 93 $\mathrm{ml}$ air, 0,4 gram serat, dan 23 kalori (Sudjianto dan Krestiani, 2009).

Sedangkan hasil penelitian yang dilaporkan oleh (Daryono \& Qurrohman, 2009) kandungan vitamin C Varietas 
Action 434 adalah 1,74 mg/100 g daging buah pada lokasi penanaman Magetan.

Pekanbaru cukup potensial untuk pengembangan tanaman hortikultura dari jenis buah-buahan, seperti melon. Permasalahan yang ditemui adalah faktor lingkungan yang kurang mendukung untuk budidaya melon. Jenis tanah di Pekanbaru didominasi oleh tanah PMK yang memiliki kandungan bahan organik yang rendah, sedikit mengandung unsur hara, dan keasaman yang tinggi. Sehingga proses pemupukan akan lebih efektif bila diberikan melalui daun. Dan Pupuk pelengkap yang diberikan, selain mengandung unsur-unsur makro juga mengandung unsur-unsur mikro yang sangat dibutuhkan. Gandasil B merupakan pupuk daun yang memenuhi persyaratan itu, dimana komposisi unsur hara makro terdiri dari 6\% Nitrogen, 20\% Fosfor, 30\% Kalium, dan 3\% Mg serta dilengkapi unsur mikro $\mathrm{Mn}, \mathrm{B}, \mathrm{Cu}, \mathrm{Co}$, Mo, dan $\mathrm{Zn}$ (Surtinah, 2004). Pada tanah yang memiliki unsur N,P, dan $\mathrm{K}$ yang rendah

\section{METODE PENELITIAN}

Penelitian ini merupakan penelitian deskriptif kualitatif yang bersumber dari penelitian yang sudah dilakukan dan sudah dipublikasikan. Fenomena yang diperoleh dari hasil penelitian tersebut, dibahas secara detail tentang faktor penyebab yang mengakibatkan umur panen buah melon lebih cepat dibandingkan di daerah sentra penanaman melon.

Penelitian tersebut menggunakan Rancangan Acak Lengkap dengan 3 kali ulangan. Perlakuan yang diberikan

\section{PEMBAHASAN}

Hasil penelitian yang dilaporkan (Surtinah, 2004), bahwa umur panen melon lebih dan kandungan bahan organik yang rendah, dengan konsentrasi $\mathrm{Fe}, \mathrm{Mn}$, dan Al yang tinggi, kondisi seperti ini dapat meracuni tanaman (Piettraszewska, 2001).

Budidaya melon yang sudah dilakukan selalu berhadapan dengan kualitas buah yang belum mencapai target sesuai dengan deskripsi melon yang ditanam. Beberapa penelitian yang pernah dilakukan membuktikan bahwa melon yang dibudidayakan di Pekanbaru waktu panennya lebih cepat dibandingkan dengan yang ditanam di daerah sentra penanaman melon.

Surtinah (2004), melaporkan bahwa melon varietas Action 434 dipanen pada umur 51 hari, sedangkan deskripsi tanaman melon tersebut adalah 65 hari setelah tanam hal ini berakibat pada rendahnya kualitas buah melon, terutama kadar gula daging buah. Tujuan penelitian ini adalah untuk mengevaluasi faktor-faktor penyebab cepatnya umur panen buah melon di Pekanbaru.

adalah lama cekaman air pada fase pertumbuhan generatif (C) yang diberikan 5 taraf yaitu: $\mathrm{C}_{0}=$ tanpa cekaman; $\mathrm{C}_{1}=$ cekaman air selama 10 hari; $\mathrm{C}_{2}=$ cekaman air selama 20 hari; $\mathrm{C}_{3}=$ cekaman air selama 30 hari; $\mathrm{C}_{4}=$ cekaman air sampai panen (seluruh perlakuan cekaman dimulai pada umur 20 hari setelah tanam). Jumlah air yang diberikan 50\% dari jumlah kebutuhan tanaman pada fase tumbuh generatif yaitu sebanyak $\pm 400 \mathrm{ml}$ (Surtinah, 2004). cepat 14 hari dibandingkan dengan deskripsi varietas melon 434, dengan kadar 
gula daging buah 8,30 brix. Hal ini

tersebut.

berpengaruh terhadap kualitas buah melon

Tabel 1. Hasil Pengamatan terhadap Umur Panen, Bobot Buah, dan Kadar Gula Daging Buah Melon saat panen dengan perlakuan lamanya cekaman air pada masa pertumbuhan generatif sebanyak $400 \mathrm{ml}$ tanaman $^{-1}$.

\begin{tabular}{|c|c|c|c|}
\hline Tingkat cekaman air & Umur Panen (hari) & Bobot Buah (g) & Kadar Gula (\% Brix) \\
\hline Tanpa cekaman & $54,89 \quad \mathrm{a}$ & $1,64 \mathrm{a}$ & $4,47 \mathrm{a}$ \\
\hline 10 Hari cekaman & $51,89 \quad b$ & $1,44 \mathrm{~b}$ & $5,33 \mathrm{~b}$ \\
\hline 20 hari cekaman & $51,89 \mathrm{~b}$ & $1,40 \mathrm{~b}$ & $6,97 \mathrm{c}$ \\
\hline 30 hari cekaman & $51,44 \quad b$ & $1,39 \mathrm{~b}$ & $7,63 \mathrm{~d}$ \\
\hline Sampai panen & 51,11 b & $1,31 \mathrm{c}$ & $8,30 \mathrm{e}$ \\
\hline
\end{tabular}

Faktor - faktor penyebab hal tersebut terjadi, antara lain;

a. Perlakuan Stress Air

Perlakuan cekaman air pada waktu pembesaran buah dapat menyebabkan tanaman stress air, dan pada tanaman yang stress akan menghasilkan hormon etilen dalam jumlah yang besar, sedangkan diketahui bahwa hormon etilen merupakan hormon yang berperan dalam proses penuaan dini pada tanaman, yang mengakibatkan proses pematangan buah melon menjadi lebih cepat dibandingkan dengan deskripsi tanaman tersebut.

Ethepon atau Ethrel yang masuk ke dalam buah akan terurai membentuk Etilen, dan Ethepon dapat memacu pematangan buah tomat dan bit (Singal, Kumud, \& Thakral, 2012). Sari, Rosmawaty, dan Gultom ( 2012) melaporkan bahwa pemberian ethrel yang bahan aktifnya etilen dapat mempercepat waktu panen buah melon. Hal ini didukung oleh penelitian yang dilakukan oleh (Ginting, Sitawati, dan Heddy, 2015), bahwa pemberian Etefon $75 \mathrm{ml}^{-1}$ dapat mempercepat pemasakan buah melon, selain itu proses pematangan buah melon menjadi seragam.

Pada penelitian yang berbeda komoditi yang dilakukan oleh (Bahar, Yusoff, \& Rasyad, 2016), diperoleh tanman cabe dengan kadar capsicin yang lebih tinggi bila di beri etilen 300- 400 ppm, dan capsicin merupakan senyawa yang terkandung di dalam buah cabai yang sudah masak fisiologis. Dilaporkan pula oleh (Murtadha, Julianti, \& Suhaidi, 2010), pemberian ethepon, dapat mempercepat proses pematangan pisang barangan yang dipanen pada tingkat kematangan $85-90 \%$ dengan hasil yang lebih bagus.

\section{b. Perlakuan Pupuk Gandasil B}

Komposisi unsur kimia yang terkandung di dalam Gandasil B adalah Nitrogen, Fosfor, Kalium, dan $\mathrm{Mg}$ serta dilengkapi unsur mikro $\mathrm{Mn}, \mathrm{B}, \mathrm{Cu}, \mathrm{Co}$, Mo, Zn. Pada tanah PMK diketahui unsur $\mathrm{Ca}$, sangat kurang bahkan tidak ada. Diduga salah satu penyebabnya adalah kurangnya unsur $\mathrm{Ca}$ pada tanah dan bahan pupuk yang diberikan ke tanaman menyebabkan tanaman melon lebih cepat mengalami penuaan. Unsur Ca merupakan unsur makro yang dibutuhkan tanaman, tetapi tidak diperoleh tanaman baik itu melalui pupuk dasar maupun pupuk sebagai perlakuan. Diketahui bahwa $\mathrm{Ca}$ bermanfaat untuk memperkuat dinding sel, sehingga tanman lebih tahan terhadap serangan bakteri dan jamur, mengaktifkan pembelahan sel, dan mengaktifkan kerja enzim. Tanaman melon merupkan tanaman yang termasuk dalam famili 
Cucurbitaceae yang sangat membutuhkan unsur $\mathrm{Ca}$ dalam pertumbuhan dan perkembangannya (Resh, 2004 dalam Sari, Ginting, dan Pangaribuan, 2013).

Menurut (Salas, Urestarazu, Bretones, dan Romero, 2005), padaang kondisi tanaman yang stress air maka penyerapan kalsium terbatas. Pada penelitian yang dianalisa ini stress air merupakan perlakuan yang diberikan. dan ketersediaan $\mathrm{Ca}$ tidak terpenuhi oleh pupuk Gandasil B yang diberikan maupun pupuk dasar, sehingga pertumbuhan dan perkembangan tanaman melon mengalami hambatn yang menyebabkan kualitas buah menjadi rendah.

Hasil penelitian yang dilaporkan oleh (Sari et al., 2013) bahwa peningkatan konsentrasi $\mathrm{Ca}$ sampai $300 \mathrm{ppm}$ meningkatkan volume buah, ketebalan daging buah, dan bobot buah. Keberadaan Kalsium mempengaruhi bentuk daun dan akar tanaman dimana ujung akar akan berwarna cokelat hal ini terjadi pada tanaman yang kekurangan Kalsium (Jones, 2005).

Pada kondisi normal yaitu kecukupan air, pemberian gandasil B 1,5 g $1^{-1}$, memberikan proses pematangan buah tercepat, dan meningkatnya konsentrasi Gandasil B tidak dapat mempercepat proses pematangan buah (Sirenden, Suparno, dan Winerungan, 2015).

\section{c. Faktor Lingkungan}

Pertumbuhan dan produksi tanaman dipengaruhi oleh faktor lingkungan dan genetik. Faktor genetik merupakan faktor keturunan yang merupakan sifat bawaan dari masing-masing varietas. Faktor lingkungan yang berpengaruh terhadap pertumbuhan dan produksi tanaman antara lain tanah. Lokasi penelitian memiliki jenis tanah PMK yang dikenal sebagai tanah yang sedikit mengandung bahan organik atau tidak mengandung bahan organik. Bahan organik yang berada di dalam tanah berperan dalam menambah unsur hara tanah, menjaga kesetabilan suhu tanah, mempertahankan kelembaban tanah, dan menggemburkan tanah sehingga memudahkan akar untuk tumbuh dan berkembang.

Pemberian pupuk kandang ke media tanam harus cukup untuk membantu proses asimilasi yang akan terjadi pada tanaman. Pemberian pupuk organik wajib diberikan pada tanah PMK. Hasil penelitian yang dilaporkan oleh (La Ode Safuan dan Bahrun,2012) bahwa dengan pemberian bahan organik pada budiadaya melon sebanyak 12,25 ton $\mathrm{ha}^{-1}$ memberikan hasil melon $2,4 \mathrm{~kg}$ pohon ${ }^{-1}$. Dan ditambahkan lagi bahwa bahan organik yang diberikan ke media tanam meningkatkan kesuburan tanah dan menambahkan kebutuhan hara bagi tanaman melon. Dan laporan penelitian yang dipublis oleh (Arfah, Harun, dan Rahmawati, 2016), menjelaskan bahwa media tanam antara tanah dengan kompos dan media tanam dengan sekam merupakan media tanam yang lebih baik untuk tanaman melon.

Pada tanah yang terjaga kelembaban, suhu dan tata udara tanah yang baik maka proses penyerapan unsur hara dan metabolisme akar menjadi lebih baik dan akan berdampak terhadap pertumbuhan dan produksi tanaman. Pada kondisi cekaman air yang diberikan, maka kelembaban tanah dan suhu tanah akan berkurang dan rendah. Hal ini berkibat kepada tanaman yang menjadi stress sehingga akan berdampak kepada munculnya hormon etilen dalam batas yang melebihi kebutuhan. Pada penelitian yang menggunakan mulsa sebagai upaya untuk menjaga kelembaban tanah dan suhu 
tanah hasil melon ternyata lebih bagus. Dilaporkan oleh (Sudjianto dan Krestiani, 2009) bahwa tanpa pemberian mulsa dengan pemberian pupuk NPK 40 gram menghasilkan produksi yang terendah.

\section{d. Keberadaan Zat Pengatur Tumbuh}

Zat pengatur tumbuh merupakan salah satu senyawa yang dibutuhkan untuk proses pertumbuhan dan produksi tanaman. Pada tanaman melon yang diberi strssing air pada masa generatifnya akan menghasilkan melon dengan waktu panen lebih cepat, seperti yang sudah dijelaskan hal ini diduga karena hormon etilen sebagai penyebabnya. Hal ini akan teratasi bila pada proses budidaya dalam kondisi yang menekan, tanaman diberi hormon penguat seperti Giberelic Acid atau Auksin dan yang lainnya. Penelitian yang sudah dilakukan oleh (Fatonah, 2012) bahwa pemberia GA dapat meningkatkan bobot buah dengan konsentrasi GA yang diberikan adalah $60-90 \mathrm{mg} \mathrm{1^{-1 }}$, dan kecepatan pertumbuhan buah terjadi pada umur 6-7 minggu setelah tanam.

\section{e. Intensitas Cahaya}

Pekanbaru termasuk salah satu daerah tropis, dimana intensitas cahaya di Pekanbaru tinggi. Tanaman melon merupakan tanaman dengan klasifikasi fisiologisnya adalah tanaman C3. Tanaman C3 merupakan tanaman yang akan mengalami fotorespirasi yang besar bila berada pada kondisi intensitas cahaya yang tinggi. Hal ini juga merupakan salah satu penyebab yang mengakibatkan tanaman stress. Pada kondisi intensitas cahaya yang tinggi maka proses katabolisme akan lebih giat terjadi. Akibatnya cadangan fotosintat yang dihasilkan dibongkar untuk proses fotorespirasi tersebut. Pada tanaman melon yang mengalami stress akibat intensitas cahaya yang tinggi akan membongkar cadangan makanan yang diprogramkan untuk produksi buah akan digunakan untuk memenuhi kecepatan respirasi yang terstimulir oleh intensitas cahaya yang tinggi tersebut. Sehingga akumulasi bahan kering yang seharusnya ditranslokasikan ke source akan digunakan untuk proses mempertahankan kehidupan tanaman.

Varietas melon Action 434 merupakan tanaman melon yang dapat dibudidayakan di dataran rendah, tetapi tetap saja tanaman melon adalah tanaman yang paling cocok dikembangkan di dataran tinggi. Modifikasi lingkungan sangat perlu untuk dilakukan dalam budidaya melon di Kota Pekanbaru.

Hasil yang diperoleh pada penelitian ini adalah semakin sedikit air yang diberikan maka bobot buah semakin rendah namun kadar gula daging semakin tinggi. Pertambahan bobot buah erat kaitannya dengan ketersediaan air pada jaringan tanaman. Perubahan bobot buah erat kaitannya dengan proses pembelahan sel pada jaringan buah tersebut. Sedangkan pembelahan sel sangat erat kaitannya dengan turgiditas sel. Lamanya cekaman air dan pemberian Gandasil B dapat memperpendek umur tanaman dan dapat meningkatkan kadargula daging buah melon, tetapi kadar gula yang dicapai belum mencapai deskripsi kadar gula melon varietas Action 434 yaitu 14\% (Brix), sedangkan hasil penelitian kadar gula daging buah hanya mencapai $8,30 \%$ (Brix). 


\section{SIMPULAN DAN SARAN}

\section{Simpulan,}

Faktor-faktor yang mempengaruhi umur panen melon di Kota Pekanbaru adalah kondisi Stress air, Kandungan unsur esensial yang dibutuhkan melon tidak diperoleh dari pupuk yang diberikan, media tanam yang digunakan diupayakan mengandung cukup bahan organik, dalam budidaya melon di Pekanbaru zat pengatur tumbuh yang dapat memperbesar buah dan mempertahankan umur tanaman perlu diberikan, dan perlu modifikasi lingkungan

\section{DAFTAR PUSTAKA}

Arfah, C. Z., Harun, F., dan Rahmawati, M. (2016). Pengaruh Media Tanam dan Konsentrasi Zat Pengatur Tumbuh Dekamon 22,43 L pada Pertumbuhan dan Hasil Tanaman Melon (Cucumis melo L). J. Kawista, 1(1), 10-14.

Bahar, E., Yusoff, A. M., dan Rasyad, A. (2016). Pengaruh Etilen terhadap Daun pada Empat Varietas Cabai (Capsicun annuum L) di Lingkungan dan Kondisi II Kabupaten Rokanhulu. J. Sungkai, 4(2), 7-12.

Daryono, B. S., dan Qurrohman, M. T. (2009). Pewarisan Sifat Ketahanan Tanaman melon (Cucumis melo L) terhadap Powdery Mildew (Podosphaera xanthii (Custag) Braun et Shinshkoff). J. Perlindungan Tanaman Indonesia, 15(1), 1-6.

Fatonah, S. (2012). Pertumbuhan Buah Tanaman Melon (Cucumis melo, L) dengan Pemberian Asam Giberelat (GA3) pada Beberapa Pemeliharaan Buah. Prosiding, Seminar UR(7), 180-182.

Ginting, R., Sitawati, dan Heddy, Y. B. S. (2015). Efikasi Zatefon untu Mempercepat Pemasakan Buah Melon (Cucumis melo L). Jurnal Produksi Tanaman, 3(3), 189-194.

Jones, B. (2005). Hydroponics A Practical Guide for The Soilless Grower. tumbuh agar situasi hampir sama dengan kondisi dataran tinggi dengan intensitas cahaya yang cukup untuk proses metabolisme.

\section{Saran,}

Saran yang perlu diperhatikan dalam budidaya melon adalah pemberian zat pengatur tumbuh untuk memperkuat buah dan memperpanjang masa hidup tanaman dan modifikasi lingkungan tumbuh sangat penting disiapkan agar hasil yang diperoleh sesuai dengan harapan.

\section{J.CRC Press Florida, 2, 45-47.}

La Ode Safuan, dan Bahrun, A. (2012). Pengaruh Bahan Organik dan Pupuk Kalium terhadap Pertumbuhan dan Produksi Tanaman Melon (Cucumis melo L). J. Agroteknos, 2(2), 69-76.

Murtadha, A., Julianti, E., dan Suhaidi, I. (2010). Pengaruh Jenis Pemacu Pematangan terhadap Mutu Buah Pisang Barangan (Musa paradisiaca L). J. Teknologi Dan Industri Pangan, 21(1), 1-10.

Piettraszewska, T., M. (2001). Effect of Aluminium on Plant Growth and Metabolism. J. Acta Biochim Olonica, 48(3), 637-686.

Salas, M. C., Urestarazu, M., Bretones, A., dan Romero, S. (2005). Melon Crop Response to Different Levels of Calsium in Nutrient Solution. J. Acta Hort., 697, 487-492.

Sari, D. P., Ginting, Y. C., dan Pangaribuan, D. (2013). Pengaruh Konsentrasi Kalsium terhadap Pertumbuhan dan Produksi Dua Varietas Tanaman Melon (Cucumis melo L) pada Sistem Hidroponik Media Padat. J. Agrotropika, 18(1), 29-33.

Sari, S., Rosmawaty, T., dan Gultom, H. (2012). Uji Penggunaan Ethrel dan NPK terhadap Produksi Melon (Cucumis melo L). J. Dinamika 
Pertanian, XXVII(3), 141-148.

Singal, S., Kumud, M., dan Thakral, S. (2012). Application of Apple as Ripening agent for Banana. J. of Natural Products and Resources, 3(1), 61-64.

Sudjianto, U., dan Krestiani, V. (2009). Studi Pemulsaan dan Dosis NPK pada Hasil Buah Melon (Cucumis melo L). J. Sains Dan Teknologi, 2(2), 1-7.
Surtinah. (2004). Pengaruh Cekaman Air dan Frekuensi Pemberian Gandasil B terhadap Kualitas Melon. J. Dinamika Pertanian, XIX(3), 325-335.

Sirenden. R T., Suparno, dan J, W. S. A. (2015). Hasil Tanaman melon (Cucumis melo L) Setelah Pemupukan Posfor dan Gandasil B pada Tanah Gambut Pedalaman. J. Agri Peat, 16(1), 28-35. 